\title{
DA MORALIDADE NO GOVERNO: O CASO DO IMPEACHMENT MOVIDO POR EDMUND BURKE CONTRA WARREN HASTINGS
}

\author{
Alexandre Toler Russo 32
}

\begin{abstract}
Nenhum servo pode servir a dois senhores. Porque, ou odiará um e amará o outro, ou se apegará a um e desprezará o outro. Vocês não podem servir a Deus e ao dinheiro (Lucas 16:13). ${ }^{33}$

Para esse tipo de homem bom, pois, conhecido não apenas de um Sócrates, mas também de um Fímbria, nada pode parecer conveniente que não seja ao mesmo tempo moralmente correto. Um tal homem, portanto, jamais arriscará pensar - e muito menos fazer - qualquer coisa que não possa ousadamente proclamar em alto e bom tom. Não é uma vergonha o fato de filósofos estarem em dúvida a respeito de questões morais conhecidas até mesmo pelos mais simples dos camponeses? (Cícero, De officiis). ${ }^{34}$

Afastada a justiça, que são, na verdade, os reinos senão grandes quadrilhas de ladrões? Que é que são, na verdade, as quadrilhas de ladrões senão pequenos reinos? Estas são bandos de gente que se submete ao comando de um chefe, que se vincula por um pacto social, e reparte a presa segundo a lei por ela aceite. Se este mal for engrossando pela afluência de numerosos homens perdidos, a ponto de ocuparem territórios, constituírem sedes, ocuparem cidades e subjugarem povos arroga-se então abertamente o título de reino, título que lhe confere aos olhos de todos, não a renúncia à cupidez, mas a garantia da impunidade (Santo Agostinho, Cidade de Deus). ${ }^{35}$
\end{abstract}

Resumo: Este artigo busca compreender como Edmund Burke defendeu a moralidade nos governos em um longo processo de impeachment contra Warren Hastings. Essa defesa, exposta nos Discursos sobre o impeachment de Warren Hastings, texto sobre o qual este artigo se baseia, centrou-se na ideia de uma moralidade - da qual faz parte um senso de justiça - inata e comum a todos os homens, independentemente de lugar ou época. O combate jurídico de Burke contra os defensores de Hastings opôs essa ideia à concepção de uma moralidade fluida - variando conforme a cultura de cada povo - a serviço das razões de estado. Para Burke, como para Cícero, há uma moralidade comum acima de qualquer discussão, e essa moralidade, capaz de identificar crimes e injustiças em qualquer lugar e em qualquer época, é conveniente e eficaz em quaisquer circunstâncias. Como Santo Agostinho, o parlamentar britânico via na justiça e na moralidade o fundamento dos governos, e nenhuma razão de estado poderia se contrapor a isso. $\mathrm{Na}$ visão do pensador irlandês, a moralidade e a justiça, em última instância fundamentadas em Deus, foram solapadas, em nome do dinheiro, pelo governo de Hastings na Índia, e a reconstituição histórica proposta neste artigo destaca os pontos controversos que serviram de substrato para as acusações de Burke no processo de impeachment.

Palavras-chaves: Edmund Burke, Warren Hastings, impeachment, justiça, moralidade.

\footnotetext{
32 Doutorando em Filosofia pela Pontifícia Universidade Católica de São Paulo.

33 Utilizou-se como referência a Nova Bíblia Pastoral, São Paulo: Paulus, 2015. (Pág. 1083.)

${ }^{34}$ Para as citações do De officiiis, de Cícero, utilizamos a edição bílingue da Loeb Classical Library: De officiis: The Loeb Classical Library. With an English Translation by Walter Miller. London and New York, 1928. "To this type of good man, then, known not only to a Socrates but even to a Fimbria, nothing can possibly seen expedient that is not morally right. Such a man, therefore, will never venture to think - to say nothing of doing - anything that he would not dare openly to proclaim. Is it not a shame that philosophers should be in doubt about moral questions on which even peasants have no doubts at all?" (Pág. 349.)

35 AGOSTINHO, Aurélio. A Cidade de Deus. Tradução, prefácio, nota biográfica e transcrições de J. Dias Pereira. 2.ed, Lisboa: Fundação Calouste Gulbekian, 1996. (Livro IV, Capítulo IV. Pág. 383.)
} 


\begin{abstract}
This paper aims to understand how Edmund Burke defended morality in government in a long impeachment process against Warren Hastings. This defense - exposed in the Speeches on the Impeachment of Warren Hastings, text upon which this article is based - relies on the idea of an inborn morality (of which a sense of justice is a part) common to all mankind, regardless of time or place. Burke's juridical struggle against Hasting's defensors was the struggle of the idea of a solid morality against the idea of a fluid morality - varying according to the different cultures - subordinated to reasons of state. In Burke's view, as well as in Cicero's view, there is a common morality above all discussion, and this morality, capable of identifying crimes and injustices regardless of time and place, is convenient and works in any circunstances. Like Saint Augustine, the British politician saw justice and morality as the fundaments of every government, and no reason of state whatsoever could disrespect justice and morality. According to the Irish thinker, morality and justice, ultimately founded in God, were tramped, for the sake of money, by Hasting's government in India, and the historical reconstitution proposed in this article highlights the controvertial issues behind Burke's accusations in the impeachment process.
\end{abstract}

Keywords: Edmund Burke, Warren Hastings, impeachment, justice, morality.

\title{
INTRODUÇÃO
}

Depois de vinte e dois anos combatendo a corrupção do governo britânico na Índia, Edmund Burke, no papel de acusador, confiou à Câmara dos $\operatorname{Lordes}^{36}$ da Inglaterra o julgamento do processo de impeachment de Warren Hastings, ex-governador-geral de Bengala. Segundo Burke, Hastings, ao longo de treze anos como representante máximo da Companhia das Índias Orientais nos domínios ingleses na Índia, cometera uma série de crimes cujas consequências nefastas não se haviam limitado às colônias britânicas, mas se tinham estendido aos fundamentos da própria monarquia inglesa. A relevância desse julgamento Burke fez questão de destacar no último discurso acusatório que proferiu, em nome da Câmara dos Comuns, contra Warren Hastings.

\begin{abstract}
Meus senhores, eu terminei: a parte dos Comuns está concluída. Com tremor vos entregamos o produto de nossos longos esforços. [...]. É um encargo sagrado. Nunca tão grande causa foi jamais submetida a um tribunal humano. [...].

[...] [E]m nome dos Comuns e deles cercado, eu declaro, diante das gerações passadas e futuras, entre as quais como um elo da grande corrente da ordem eterna nos encontramos - eu invoco esta nação e o mundo como testemunhas -, que os Comuns não se esquivaram de nenhum trabalho, que nós não somos culpados de prevaricação alguma, que não nos comprometemos com a criminalidade e que não tememos jamais ódio de nenhuma espécie no curso dessa longa guerra travada contra os crimes, os vícios, a exorbitante riqueza e a enorme e extremamente poderosa influência da corrupção oriental. Esta guerra (...) nós a travamos por vinte e dois anos, e os sete últimos anos desse conflito tiveram como palco o vosso tribunal ${ }^{37}$.
\end{abstract}

\footnotetext{
36 O parlamento britânico é dividido em duas casas: a baixa é conhecida como Câmara dos Comuns e a alta é a Câmara dos Lordes.

${ }^{37}$ Para a maioria das citações diretas dos Discursos sobre o Impeachment de Warren Hastings, utilizamos The Works of the Right Honourable Edmund Burke. Vol. VIII. Speeches on the Impeachment of Warren Hastings, and Letters, London: George Bell and Sons, 1877. " My lords, I have done; the part of the Commons is concluded. With a trembling we consign this product of our long, long labours to your charge. (...) It is a sacred trust. Never before was a cause of such magnitude submitted to any human tribunal.

(...) in the name of the Commons, and surrounded by them, I attest the retiring, I attest the advancing generations, between which, as a link in the great chain of eternal order, we stand. - We call this nation, we call the world to witness, that the Commons have shrunk from no labour; that we have been guilty of no prevarication; that we have made no compromise with crime; that we have not feared any odium whatsoever, in the long warfare which we have carried on with the crimes with the vices - with the exhorbitant wealth - with the enormous and overpowering influence of Eastern corruption. This
} 
Salta à vista, nesse trecho do discurso proferido por Burke em nome dos Comuns, a ideia de sacralidade da justiça. Essa ideia, aprofundada no restante da fala do político irlandês ${ }^{38}$, é a de uma justiça que, parte integrante da moralidade inscrita por Deus no coração dos homens, orienta-os nas ações individuais e coletivas, precedendo e viabilizando a história da humanidade. Com efeito, essa história, na medida em que se confunde com a própria civilização, não existe senão sobre o solo firme da moralidade comum a todos os seres humanos. Quando a ação humana calca a justiça sob os pés, o chão moral das instituições civilizatórias treme ameaçadoramente.

[...] [V]ossa casa ainda está de pé como um grande edifício. Devo dizer, porém, que ela resiste em meio às ruínas resultantes do maior terremoto moral jamais sentido neste nosso planeta. [...] [Q]uis a Providência Divina nos colocar em uma situação na qual a todo o instante parece que vemos o prenúncio de alguma grande mudança. Existe, no entanto, uma coisa - e somente uma coisa - que desafia toda e qualquer mudança. Uma coisa que existia antes do mundo [...]. Eu falo da Justiça. Aquela Justiça que, emanando da Divindade, tem lugar no coração de cada um de nós; que nos foi dada como guia para nós mesmos e em relação aos outros; que permanecerá mesmo depois da destruição deste mundo; que será nossa advogada de defesa ou nossa acusadora diante do grande Juiz ${ }^{39}$.

A história das ações humanas mostra não ser prudente abrir mão da justiça, pois, desprezando-a, o homem não tem como sustentar sozinho as estruturas da própria vida em sociedade. Aviltada a justiça, formas de governo, leis, instituições e mesmo a liberdade compartilham com a humanidade um só e aterrador destino: a destruição. Somente a justiça mantém todos de pé.

[...] [O]s Comuns irão compartilhar o vosso destino. Nada há de tão sinistro que vos possa acontecer em que não estejamos envolvidos. [...].

[...] [S]e deveis cair, então caireis. Mas se permanecerdes de pé - o que, creio, deva acontecer -, juntamente com a sorte desta antiga monarquia e das antigas leis e liberdades deste grande e ilustre reino, então que vossa figura não se abale nem na honra nem no poder. Sede o porto seguro e o ornamento da virtude, não o substituto dela. Desejo-vos vida longa, para que ao longo dela sejais sempre o terror dos tiranos, o refúgio das nações aflitas e o templo sagrado para sempre habitado por uma Justiça inviolável ${ }^{40}$.

war (...) we have waged for twenty-two years, and the conflict has been fought at your lordship's bar for the last seven years." (Pág. 439.)

${ }^{38}$ Neste artigo, identificamos Burke por meio de suas diversas facetas: irlandês, britânico, inglês e político. A Irlanda, na época de Burke, fazia parte do Império Britânico, razão pela qual retratamos Burke ao mesmo tempo como "irlandês" e "britânico". Como a Inglaterra era o centro do Império Britânico, e como Burke muitas vezes se dizia "inglês", nós também o chamamos de "inglês". Por fim, Edmund Burke era um político a serviço do Império Britânico, razão pela qual, neste artigo, nós o identificamos como "político irlandês", "político britânico" e "político inglês".

${ }^{39}$ Burke, 1877: “(...) your house yet stands; it stands as a great edifice; but let me say that it stands in the midst of ruins that have been made by the greatest moral earthquake that ever convulsed and shattered this globe of ours. (...) it has pleased Providence to place us in such a state, that we appear every moment to be upon the verge of some great mutations. There is one thing, and one thing only, which defies all mutation; that which existed before the world (...). I mean Justice; that Justice, which, emanating from the Divinity, has a place in the breast of every one of us, given us for our guide with regard to ourselves and with regard to others, and which will stand after this globe is burned to ashes, our advocate or our accuser before the great Judge (...). (Págs. 439 e 440.)

40 Burke, 1877: “(...) the Commons will share in every fate with your lordships; there is nothing sinister which can happen to you, in which we shall not be involved (...).

(...) if you must fall, may you so fall! But if you stand, and stand I trust you will, together with the fortune of this ancient monarchy - together with the ancient laws and liberties of this great and illustrious kingdom, may you stand as unimpeached in honour as in power; may you stand not as a substitute for virtue, but as an ornament of virtue, as a security 
O poder real que mantém firmes homens e sociedade é a moralidade que constitui o solo da vida civilizada. A história nos mostra que não é prudente ser injusto, - ou imoral, o que vem a ser a mesma coisa -, porém, ela mesma não é a origem de sua própria existência e explicação. Ela pode muito bem servir de preceptora de prudência, mas não de fonte de princípios. Se alguém desejar entender o poder que viabiliza a civilização, deverá voltar-se, não para a história, mas para a moralidade inscrita em seu coração pela Divindade. O poder sobre os homens e a sociedade, aquele poder que torna possível e organiza a vida em conjunto e que chamamos de política, não é construído pela história e na história, mas emana de um princípio que a fundamenta, cria e transcende. Burke condensou essas ideias em uma carta que escreveu a William Markham:

[M]eus princípios permitem-me formar meu julgamento sobre os homens e as ações na história, assim como o fazem na vida comum; e não são formados por acontecimentos e personagens, presentes ou passados. A história é preceptora da prudência, não dos princípios. Os princípios da verdadeira política são aqueles da moralidade ampliada; e eu não irei admitir nenhum outro além desses, nem agora nem nunca ${ }^{41}$.

Se quiser preservar a sociedade, o político (ou governante) deverá ser prudente. Sendo prudente, agirá de acordo com a moralidade. Agindo de acordo com a moralidade, será justo. E a justiça ser-lhe-á conveniente, pois nela está a garantia do bem-estar da comunidade na qual ele mesmo se insere. Como o bem-estar da comunidade é essencial para o bem-estar de indivíduos naturalmente propensos a viver conjuntamente $^{42}$, não há conflito - analisada com propriedade a questão - entre interesse individual,

\footnotetext{
for virtue; may you stand long, and long stand the terror of tyrants; may you stand the refuge of afflicted nations; may you stand a sacred temple, for the perpetual residence of an inviolable justice. (Págs. 440 e 441.)

${ }^{41}$ Citação da carta de Burke a Markham feita por Peter J. Stanlis no artigo "Edmund Burke's Legal Erudition and Practical Politics: Ireland and the American Revoltution". In: First Principles (Web Journal), 2010. (Acesso em 31 de agosto de 2017 : www.firstprinciplesjournal.com.) "My principles enable me to form my judgement upon man and actions in history, just as they do in current life, and are not formed out of events and characters, either present or past. History is a preceptor of prudence not of principles. The principles of true politics are those of morality enlarged; and I neither now do or ever will admit of any other."

${ }^{42}$ Burke compartilhava da célebre definição aristotélica do homem como animal político. Cícero, - uma das figuras que mais influenciaram Burke -, dentro do espírito aristotélico, definiu bem esse sentimento gregário do homem em uma passagem do De officcis (edição Loeb, 1928, págs. 161 e 163): “And again, as swarms of bees do not gather for the sake of making honeycomb but make the honeycomb because they are gregarious by nature, so human beings - and to a much higher degree - exercise their skill together in action and thought because they are naturally gregarious. (...) And it is not true, as certain people maintain, that the bonds of union in human society were instituted in order to provide for the needs of daily life; for, they say, without the aid of others we could not secure for ourselves or supply to others the things that nature requires; but if all that is essential to our wants and confort were supplied by some magic wand, as in the stories, then every man of first-rate ability could drop all other responsibility and devote himself exclusively to learning and study. Not at all. For he would seek to escape from his loneliness and to find some one to share his studies; he would wish to teach, as well as to learn; to hear, as well as to speak." ["E, novamente, tal como as abelhas não se juntam com o propósito de fazer a colmeia, mas fazem a colmeia pelo fato de serem gregárias por natureza, também os homens - em grau muito mais elevado - exercem juntos sua habilidade de ação e pensamento porque são naturalmente gregários. (...). E não é verdade, como afirmam certas pessoas, que os laços de união da sociedade humana tenham sido instituídos no intuito de prover as necessidades da vida cotidiana; pois, dizem eles, sem a ajuda dos outros não poderíamos assegurar para nós mesmos ou fornecer a outrem as coisas requeridas pela natureza; mas se tudo o que é essencial para nossas necessidades e conforto nos fosse dado como num passe de mágica, a exemplo do que acontece nos contos, então todo e qualquer homem de grande habilidade poderia deixar de lado as demais responsabilidades para se dedicar exclusivamente ao aprendizado e ao estudo. Nada mais falso. Pois iria ele buscar escapar da solidão e encontrar alguém com quem compartilhar seus estudos; iria ele querer ensinar e aprender, escutar e falar.’”
} 
interesse coletivo, moralidade e justiça. É, pois, dever do governante ser justo, para o seu próprio bem e para o bem da sociedade. Nos Discursos sobre o impeachment de Warren Hastings, assim como nos demais escritos de Burke, uma reflexão desse tipo não aparece de forma teórica e sistemática, isto é, à feição de uma filosofia. Emerge, na realidade, de maneira irregular, em meio a uma retórica típica das tribunas que serviam de palco para a oratória dos políticos.

Edmund Burke era um político consciente da tradição filosófica por trás de sua retórica ${ }^{43}$. Conhecia muito bem as ideias da escola socrática, sobretudo na forma como Cícero as transmitira ao Ocidente, pois Cícero lhe servia de exemplo profissional e de fonte intelectual permanente ${ }^{44}$. Foi, aliás, a ideia de uma moralidade inata aos homens, na qual se inscrevia um senso comum de justiça igualmente inato, defendida por Cícero em diversos de seus escritos, entre eles o Tratado sobre os Deveres (De officis), que Burke utilizou em sua acusação contra os crimes de Warren Hastings na Índia, crimes esses que violavam essa moralidade e esse senso de justiça comum a todos os homens.

Essa verdadeira lei moral inscrita no coração humano era para Burke um dom de Deus, especificamente do Deus judaico-cristão, nesse ponto diferindo pelo menos em parte de suas fontes filosóficas da antiguidade greco-romana. O político irlandês, cristão que era, não desprezava o fundamento religioso da moral; pelo contrário, jamais se furtava a expor em sua argumentação a importância de se obedecer na política a essa lei divina inscrita na alma humana na forma de moralidade e senso de justiça. Além disso, em sua visão, a religião cristã exigia ainda um dever específico de todos os governantes, qual seja, o de servir às pessoas, zelando pelo seu bem-estar. Com efeito, Jesus Cristo, sendo ele próprio Deus, fonte de todo o poder do universo, ao viver na terra entre os homens não buscou subjugá-los, mas servi-los:

[...] [T] endes aqui também as luzes da nossa religião, (...) os bispos da Inglaterra. (...). [T]endes a imagem verdadeira da igreja primitiva, na sua forma antiga (...). Aqui tendes os representantes dessa religião, que dizem ser o Deus deles um Deus de amor, que dizem ser a caridade o próprio espírito vital de sua instituição - uma religião que odeia a opressão porque o Deus que adoramos, quando apareceu entre nós em forma humana, não se revelou em Sua grandeza e majestade, mas em Sua simpatia com os mais humildes dos homens, estabelecendo assim o princípio fundamental segundo o qual o bem-estar dessas pessoas é o objetivo de todo e qualquer governo, visto que (...) o próprio Mestre da Natureza resolveu Se fazer mostrar em uma situação de subordinação ${ }^{45}$.

\footnotetext{
43 Peter J. Stanlis, no artigo intitulado "Edmund Burke's Legal Erudition and Practical Politics: Ireland and the American Revoltution". In: First Principles (Web Journal), 2010, acesso em 31 de agosto de 2017: www.firstprinciplesjournal.com, faz o seguinte comentário: "To Burke, a knowledge and understanding of the liberal arts, from the ancient Greek and Roman classics to his own era, was an essential background dimension in legal education. He believed that law had to have a philosophical basis (...)." ["Para Burke, o conhecimento e a compreensão das artes liberais, desde os antigos clássicos gregos e latinos até a sua própria época, eram os pré-requisitos essenciais da educação legal. Para ele a lei tinha de ter uma base filosófica (...)"'].

44 Peter J. Stanlis, no artigo intitulado "Edmund Burke's Legal Erudition and Practical Politics: Ireland and the American Revoltution”. In: First Principles (Web Journal), 2010, acesso em 31 de agosto de 2017: www.firstprinciples journal.com., faz o seguinte comentário: “Among the ancients, he was very attracted to Aristotle's treatises on Politics and Ethics, to Cicero's De officiis and De legibus, and to such Roman stoics as Epitectus." ("Entre os antigos, ele apreciava especialmente os tratados de Aristóteles sobre Politica e Ética, as obras de Cícero intituladas De officiis e De legibus e os escritos de estoicos como Epíteto"). ${ }^{45}$ Esta citação encontra-se nas páginas 76 e 77 do volume X de The Works of the Right Honourable Edmund Burke, London: John C. Nimmo, 1887. “(...) you have here also the lights of our religion, (...) the bishops of England (...) you have that true image
} 
Em última instância, o dever do governante é respeitar a lei de Deus - ou seja, respeitar a moralidade e o senso de justiça inato aos homens - e agir como Cristo, antes servindo do que sendo servido. Ao governante, ou político, é confiada a condução do rebanho humano, rebanho que na verdade é de Deus e cuja condução por parte de reis e soberanos não pode ser entendida senão mediante a ideia de um encargo sagrado compreendido ao mesmo tempo como direito e dever. É essa a moralidade que se espera - na figura dos governantes - de qualquer governo. “Os direitos dos soberanos são, sem sombra de dúvida, direitos sagrados, e assim são propriamente justificados em qualquer país do mundo, pois exercidos devem ser em benefício do povo e em obediência àquela grande finalidade em função da qual Deus concede poder a um ou a mais homens" ${ }^{\prime 4}$.

Firmando seu discurso na moralidade comum da humanidade, inscrita por Deus no coração de cada ser humano, Burke combateu os argumentos dos defensores de Hastings, firmados na ideia de que o bom e o mau, o certo e o errado, o justo e o injusto variavam conforme as diferenças culturais. Para ele, não há de se falar em "moralidade geográfica”, como se a justiça fosse uma para gregos e outra para judeus, uma para cristãos e outra para não cristãos, uma para indianos e outra para ingleses.

\begin{abstract}
Nós negamos categoricamente esse princípio. Eu estou autorizado a negá-lo e a isso sou chamado. E tendo estabelecido, de maneira geral, o que ele entende ao dizer que as mesmas ações não possuem as mesmas qualidades na Ásia e na Europa, mostramos aos senhores que esses cavalheiros conceberam o plano de uma moralidade geográfica, segundo a qual os deveres dos homens, nas situações públicas e nas situações privadas, não devem ser governados por sua relação com o Grande Governante do Universo, ou mesmo por sua relação com a humanidade em geral, mas pelos climas, pelos graus de longitude e pelos paralelos, não da vida, mas das latitudes: como se, cruzada a linha equinocial, todas as virtudes morressem, assim como morrem certos insetos quando a cruzam (...).

Nós protestamos contra essa moralidade geográfica; o Sr. Hastings não irá se esconder atrás dela. (...). [A]s leis da moralidade são as mesmas em toda a parte, e não há um só ato que passe por extorsão, peculato, suborno ou opressão na Inglaterra que não seja igualmente extorsão, peculato, suborno ou opressão na Europa, na Ásia, na África e no mundo inteiro ${ }^{47}$.
\end{abstract}

of the primitive church, in its ancient form (...). You have the representatives of that religion which says that their God is love, that the very vital spirit of their institution is charity, - a religion which so much hates oppression, that, when the God whom we adore appeared in human form, He did not appear in a form of greatness and majesty, but in sympathy with the lowest of the people, and thereby made it a firm and ruling principle that their welfare was the object of all government, since the (...) Master of Nature chose to appear Himself in a subordinate situation."

${ }^{46}$ Burke, 1877: "The sovereign's rights are undoubtedly sacred rights, and ought to be so held in every country in the world, because exercised for the benefit of the people, and in subordination to that great end for which alone God has vested power in any man or any set of men." (Págs. 4 e 5.)

47 Utilizamos, para essa citação, The Works of the Right Honourable Edmund Burke. Volume the Ninth, London: John C. Nimmo, 1887. “(...) we positively deny that principle. I am authorized and called upon to deny it. And having stated at large what he means by saying that the same actions have not the same qualities in Asia and in Europe, we are to let your Lordships know that these gentlemen have formed a plan of geographical morality, by which the duties of men, in public and in private situations, are not to be governed by their relation to the Great Governor of the Universe, or by their relation to mankind, but by climates, degrees of longitude, parallels, not of life, but of latitudes: as if, when you have crossed the equinoctial, all the virtues die, as they say some insects die when they cross the line (...).

This geographical morality we do protest against; Mr. Hastings shall not screen himself under it (...). (...) the laws of morality are the same everywhere, and there is no action which would pass for an act of extortion, of peculation, of bribery, and of oppression in England, that is not an act of extortion, of peculation, of bribery, and oppression in Europe, Asia, Africa, and all the world over." (Pág. 375.) 
Com base no relato de testemunhas e munido de evidências documentais, Edmund Burke acusou Warren Hastings de roubar e oprimir os indianos que se encontravam sob o governo da britânica Companhia das Índias Orientais. Para ele, "negros" e "brancos"48 eram perfeitamente capazes de perceber, graças à razão e à moralidade que lhes eram comuns, a imoralidade de atos criminosos cujas más conseqüências, abalando a estrutura da vida civilizada, não se limitavam à Índia, que vivia uma profunda crise econômica, mas se estendiam à própria Inglaterra, que progressivamente ia caindo nas mãos de uma elite corrompida e ávida pelo controle da monarquia mediante o emprego dos mesmos recursos excusos utilizados no Oriente. Foi, portanto, em nome da civilização e da humanidade que Edmund Burke buscou a condenação de Warren Hastings em um longo processo de impeachment transcorrido nos tribunais ingleses.

É a história desse processo de impeachment que, em linhas gerais, buscaremos narrar no restante do artigo. Não se trata de uma reconstituição completa dos fatos, em todos os seus timbres, mas de uma contextualização feita para facilitar o acesso ao coração do argumento do irlandês, qual seja, o da necessidade de moralidade a qualquer governo do mundo. Sobre essa moralidade no governo, de um ponto de vista burkeano, versará a terceira e última parte do artigo.

\section{EDMUND BURKE E O IMPEACHMENT DE WARREN HASTINGS}

No tempo transcorrido entre o nascimento e a morte de Burke o primeiro Império Britânico tomou forma. Ao longo da carreira do político irlandês, uma porção importante - a América - desse domínio foi perdida, a despeito de seus protestos, enquanto outra - a Índia - foi consolidada e teve o governo reformado, em parte graças aos seus esforços ${ }^{49}$. Dentro de uma visão burkeana da história, muito da formação desse império pode e deve ser explicado pelas diversas facetas da interação mundana, mas isso não exclui o papel da Providência Divina ${ }^{50}$ nas questões humanas. O modo como um homem chega ao poder ou como uma nação se torna um império é em larga medida obscuro e misterioso e, no cômputo geral, não é tão manipulável quanto a maneira como os homens ou as nações exercem o poder que lhes cai nas mãos. Era assim que Burke enxergava a questão indiana: tinha ele consciência da forma obscura - e mesmo moralmente questionável -, porém, misteriosa, pela qual os britânicos haviam conquistado diversos territórios na Índia, todavia, sua principal preocupação era a de que os governantes ingleses exercessem de forma justa o poder que lhes fora confiado por Deus.

\footnotetext{
${ }^{48} \mathrm{Na}$ época de Burke, os britânicos, que se consideravam "brancos", chamavam os indianos de "negros".

${ }^{49}$ Burke, em diversos discursos, buscou uma conciliação com a América, pois, achava ele, a Inglaterra vinha agindo de maneira injusta com sua colônia. O irlandês não desejava a guerra que acabou resultando na independência dos Estados Unidos. Quanto aos problemas na Índia, Burke foi ferrenho defensor da reforma radical de um governo marcado pela corrupção.

50 Para entender a visão cristã de Burke a respeito da Providência Divina, sugere-se a leitura da obra de Francis Canavan intitulada Edmund Burke: Prescription and Providence, Durham: Carolina Academic Press, 1987.
} 
É, pois, o exercício do poder que parece ser a questão fundamental do processo de impeachment de Warren Hastings. Burke acusou o ex-governador-geral de Bengala de governar de maneira injusta e imoral, ameaçando com isso a sobrevivência de um império cuja administração lhe fora delegada pelo parlamento britânico e cujo domínio, em última instância, pela vontade divina havia caído nas mãos da Coroa inglesa. Hastings, por meio de seus advogados, defendeu-se dizendo que a correção de seus atos deveria ser, no final das contas, avaliada em função da força e da riqueza que, por meio da administração dos interesses da Companhia das Índias Orientais, conseguira ele angariar para a Inglaterra. Em suma, tratou-se de um embate entre o moralismo político, herdeiro da filosofia desenvolvida no Cristianismo e dos conceitos da tradição filosófica socrática abraçada por homens como Cícero, e do relativismo moral calcado nas razões de estado.

Em 1772, aos quarenta anos de idade, após toda uma juventude dedicada aos serviços da Companhia das Índias Orientais, Warren Hastings foi nomeado governador-geral de Bengala. Sua nomeação tinha um propósito explícito: conter, por meio da centralização político-administrativa do governo, a corrupção que dia após dia se impregnava na estrutura dos domínios britânicos na Índia. A história dessa corrupção está diretamente ligada ao crescimento da importância da Companhia das Índias Orientais em território indiano, fato que teve início com o enfraquecimento do Império Mogol.

O Império Mogol, fundado em 1526 por Babur, estendeu-se por quase toda a Índia ${ }^{51}$ e durou mais de trezentos anos. Seus líderes, que se diziam descendentes diretos do mongol Genghis Khan, tiveram de construir um domínio em meio a um amálgama cultural formado de elementos autóctones e de influências de antigos conquistadores. Em síntese, misturavam-se no Império Mogol costumes, leis e instituições hindus e muçulmanos. No século XVIII, essa potência começou a declinar, e em 1707, ano da morte de Aurangzeb (último imperador de fato), teve início a desintegração do império. Levas de invasores persas e afegãos devastaram o norte da Índia, ao mesmo tempo que uma confederação de chefes guerreiros hindus, os Marathas, retomaram uma revolta iniciada no século anterior contra o jugo mogol, expandiram seu controle sobre a Índia central e atacaram continuamente os territórios imperiais. Mais grave, porém, foi a traição dos governadores provinciais mogóis que, estabelecendo uma independência de fato em relação a Delhi, procuraram fundar dinastias hereditárias em estados como Bengala e Oudh e na região carnática. A sanha dos princípes indianos por poder e riqueza criou um ambiente de grande instabilidade política marcado por guerras, assassinatos, crises sucessórias e golpes de estado.

\footnotetext{
${ }^{51}$ Jorge Flores, no livro intitulado Nas Margens do Hindustão: O Estado da Índia e a expansão mogol,ca. 1570-1640: Imprensa da Universidade de Coimbra. Julho, 2015, diz o seguinte: “O império mogol nasceu em 1526, quando um turco chagatai chamado Zahir-ud-din Muhammad Babur, padshah de Cabul, venceu os afegãos na batalha de Panipat, arredores de Deli. Durante (...) quase dois séculos (...) seu estado haveria de crescer paulatinamente em várias direcções geográficas e aglutinar diferentes zonas culturais da Índia. Não sem recuos e revezes, logrou alargar-se territorialmente até à Caxemira a norte, ao Cinde a oeste e a Chatigão (no Bengala oriental) para este. A sua dimensão máxima foi alcançada em 1689 quando, após a conquista do sultanato de Golconda, chegou a dominar Jinji, no extremo sul da península indiana. Nesse preciso momento, o espaço político do império quase se confundia com a própria geografia física do subcontinente.” (Pág. 31.)
} 
Os europeus - notadamente os franceses e os ingleses - que então disputavam na Índia novas oportunidades comerciais logo perceberam que podiam tirar proveito da situação. Em 1740, os franceses foram os primeiros a intervir decisivamente nas disputas internas dos estados indianos, extraindo novos privilégios e novas concessões das facções vitoriosas por eles apoiadas e reforçando, assim, sua posição diante dos ingleses. Os ingleses entenderam que a manutenção de seus negócios exigia a adoção de métodos iguais aos empregados pelos franceses. Nesse contexto, emergiu a liderança de Robert Clive, por intermédio de quem os britânicos conquistaram - antes de 1750 - toda a região carnática, submetendo-a ao governo-fantoche de um nababo que lhes devia a existência. Em 1756, novas hostilidades eclodiram entre Inglaterra e França. Siraj al-Daula, nababo de Bengala, exasperado com abusos comerciais cada vez maiores e contando com o apoio francês, atacou os ingleses e os fez recuar dos locais em que eles estavam estabelecidos. No ano seguinte, o "contra-ataque" de Clive foi decisivo: depois de recapturar Calcutá, o britânico venceu definitivamente os exércitos do nababo na batalha de Plassey e colocou o títere Mir Jafar no trono de Bengala ${ }^{52}$.

O interesse financeiro inglês na Índia adquiriu com as vitórias de Clive um poder sem precedentes. A Companhia das Índias Orientais, originalmente uma empresa comercial ${ }^{53}$, passou de fato a governar pessoas e territórios, estruturando, rapidamente, um sistema de relação promíscua entre a política e a economia. A corrupção aprofundou-se ainda mais quando, em 1765, negociou-se com o imperador mogol o Tratado de Allahabad. Por meio desse acordo, a "E.I. Co." ganhou o direito de coletar impostos e administrar a justiça civil em Bengala, adquirindo, assim, uma quase soberania sobre seus territórios indianos.

As transações escusas da "Companhia" começaram a comprometer a governabilidade dos domínios ingleses recém-conquistados. Preocupados, os acionistas da "John Company", todos eles muito influentes no parlamento e na corte, decidiram recuperar o controle da situação por meio da centralização político-administrativa dos negócios. Foi assim que, em 1772, Warren Hastings assumiu o posto de

\footnotetext{
${ }^{52}$ Frederick G. Whelan, no livro intitulado Edmund Burke and India: political morality and empire, Pittsburgh: University of Pittsburgh Press, 1996, escreveu o seguinte: “(...) Clive decisively defeated the nawab's army at Plassey, and (by prearrangement) placed a more friendly pretender, Mir Jafar, on the throne of Bengal”. [“(...) Clive derrotou o exército do nababo, de uma vez por todas, em Plassey, e - isso já estava articulado - colocou um pretendente mais amigável, Mir Jafar, no trono de Bengala.”] (Pág. 35.)

${ }^{53}$ John T. Noonan Jr., no artigo intitulado "The Bribery of Warren Hastings: The Setting of a Standard for Integrity in Administration". In: Hofstra Law Review. Vol. 10, 1982, fez o seguinte comentário sobre a Companhia das Índias Orientais: “The Company's supervision was further diluted by its structure. The East Índia Company - 'the United Company', 'the E.I. Co.', 'John Company', or simply 'the Company' - was a joint stock company in which every holder of over 500 pounds of stock possessed one vote, so that domination by a few big stockholders did not occur. Instead, the directors, occasional fallingouts aside, tended to perpetuate themselves. The directors' interest in patronage was often as keen as their interest in protecting the stockholders. Their official position was the obvious one of requiring integrity in the Company's employees; but there were splendid opportunities for the employees to develop reciprocal relationships with the directors." ("A supervisão da Companhia foi posteriormente diluída por sua estrutura. A Companhia das Índias Orientais - a 'United Company', a 'E.I. Co.', a 'John Company' ou, simplesmente, a 'Companhia' - era uma sociedade anônima na qual todo acionista detentor de cerca de 500 libras em ações tinha direito a um voto, de forma que o domínio por parte de alguns grandes acionistas não acontecia. Os diretores, no entanto, - alguns desentendimentos à parte -, tendiam a perpetuar-se no poder. O interesse dos diretores no patronato era em geral tão grande quanto o interesse em proteger os acionistas. A posição oficial, obviamente, era a exigência de integridade dos empregados da Companhia; mas havia esplêndidas oportunidades para o desenvolvimento de relações recíprocas entre empregados e diretores.”) (Pág. 1077.)
} 
governador-geral de Bengala. Incumbido, porém, de frear a corrupção, Hastings, de acordo com Burke, sistematizou-a de tal forma que ela se tornou a própria essência do governo britânico na Índia, envolvendo governantes e governados num círculo vicioso de troca de favores que envolvia a própria Inglaterra.

[Hastings] não apenas ofereceu e recebeu suborno acidentalmente. [Ele] elaborou planos e sistemas de governo com o propósito explícito de acumular para si mesmo propinas (...). [R]ebaixou-se à lama do peculato e da corrupção. [Não foi] tão-somente um ladrão comum da coisa pública, mas, encabeçando um sistema inteiro de corrupção, foi o grande comandante de uma verdadeira gangue ${ }^{54}$.

As primeiras investigações parlamentares a respeito da corrupção na Índia iniciaram-se em 1767, quando os Rockingham Whigs, grupo político do qual Burke fazia parte, opuseram-se a uma interferência nos negócios da Companhia das Índias Orientais em nome das prerrogativas legais da empresa. Cinco anos depois, quando os acionistas da "E.I. Co." estavam sendo pressionados para "colocar a casa em ordem", o próprio Burke recebeu convite - mas não o aceitou - para assumir a função que, posteriormente, viria a ser desempenhada por Warren Hastings. Em 1773, a despeito da contínua oposição dos Rockingham Whigs, o primeiro grande documento legislativo a respeito da Índia foi aprovado: a Lei Regulatória de Lorde North, que estabeleceu uma forma limitada de controle parlamentar sobre o império indiano. O poder do governador-geral de Bengala não foi suprimido (Hastings, que em 1773 já se encontrava nesse cargo, foi nele mantido), mas dividido com um conselho cujos membros eram nomeados pelo governo e com uma suprema corte supostamente independente. Essa lei regulatória foi a primeira ação clara de supervisão e controle do Estado britânico sobre seus territórios ultramarinos e, mais propriamente, sobre a Companhia das Índias Orientais.

No início da década de 1780, em parte devido a informações fornecidas pelos adversários de Hastings em Bengala, era forte na Inglaterra a opinião de que a "Lei de Lorde North" já não dava conta da situação na Índia. Burke e outros políticos compartilhavam dessa visão. Entre 1781 e 1783, o irlandês estudou com profundidade a questão indiana. Nessa época, escreveu diversos relatórios condenando o governo da "Companhia" de maneira geral e as políticas de Hastings de modo particular. O resultado desses estudos foi que Burke, antes simpático à autonomia administrativa da "John Company", tornou-se um contundente defensor do controle e da supervisão estatal sobre a empresa britânica. Entre novembro e dezembro de 1783, ele ajudou a elaborar o Fox's East India Bill, que, conquanto não tenha sido aprovado, exerceu influência sobre o projeto de lei concebido - e posto em prática - na administração de William Pitt acerca do assunto. O Pitt's East Indian Act de 1784 foi uma espécie de meio termo entre a autonomia administrativa da "United Company" e a supervisão estatal. Burke não era exatamente um entusiasta dessa

\footnotetext{
${ }^{54}$ Noonan Jr., 1982, citando Burke: "He 'did not only give and receive bribes accidentally'. He 'formed plans and systems of government for the very purpose of accumulating bribes and presents to himself.' He descended into 'the muck and filth of peculation and corruption'. He was 'not only a public robber himself, but the head of a system of robbery, the captain-general of the gang"”. (Pág. 1073.)
} 
solução, porém, não a criticou ostensivamente. Sua principal preocupação, nesse período, era o levantamento do maior número possível de evidências capazes de embasar um processo de impeachment contra Warren Hastings, que, em 1785, havia acabado de deixar o governo de Bengala.

Já no tempo de Burke o recurso do impeachment era um elemento antigo da constituição inglesa. Destinada a controlar as ações dos altos executivos do governo em nome da lei e da liberdade, a ferramenta do impeachment fora bastante utilizada em um passado não tão longínquo, porém, no século XVIII, não vinha sendo usualmente empregada. Para os ingleses, impeachment não significava necessariamente afastamento do cargo, mas sim condenação por crimes graves cometidos no exercício dele $^{55}$. Na opinião de Burke, Hastings havia cometido graves crimes durante seu governo em Bengala, razão pela qual deveria enfrentar um processo de impeachment.

A instauração desse processo não foi simples. Hastings, afinal de contas, havia sido politicamente forte o suficiente para resistir incólume ao longo de treze anos e cinco governos diferentes, North, Rockingham, Shelburne, a Coalisão e Pitt, indício de que sua condenação não seria nada fácil. Burke tinha consciência disso, conhecedor que era da promiscuidade dos interesses político-econômicos da elite britânica e de sua ramificação indiana. Tratava-se, para ele, muito menos de uma causa prática, assumida com vistas numa provável vitória, e muito mais de uma questão de integridade pessoal, uma justificativa moral perante as gerações futuras ${ }^{56}$.

Em 1786, Hastings foi acusado formalmente diante dos Comuns de haver cometido diversos tipos de crimes (high crimes and misdemeanors) durante seu mandato como governador-geral de Bengala. Foram inicialmente formulados vinte e dois artigos de acusação, mas os Comuns, sob a pressão do tempo exigido pelos procedimentos parlamentares, condenaram Hastings por vinte e um deles. Esses vinte e um artigos foram encaminhados à Câmara dos Lordes, casa incumbida da palavra final sobre o impeachment. Também movidos pelo desejo de simplificar a questão, a fim de tornar mais rápido todo o processo, Burke e os demais acusadores condensaram a argumentação em quatro tópicos centrais que resumiam os principais crimes cometidos por Hastings na Índia: propinas, contratos, Benares e begams de $\mathrm{Oudh}^{57}$. Apoiados nesses pontos, os acusadores concluíram sua tarefa diante dos lordes em 1791.

\footnotetext{
55 Noonan Jr., 1982: "When Hastings returned in 1785 (...), Burke, again in opposition, worked for his impeachment impeachment in the British sense being not necessarily removal from office but conviction of high crimes committed while in office". [Quando Hastings retornou em 1785 (...), Burke, novamente na oposição, trabalhou pelo seu impeachment - o impeachment, na acepção britânica, não sendo necessariamente o afastamento do cargo, mas a condenação por graves crimes cometidos no exercício do cargo".] (Pág. 1081.)

${ }^{56}$ Noonan, Jr., 1982, citando Burke. "'Speakinf for myself, he wrote, 'my business is not to consider what will convict Mr. Hastings (a thing we all know to be impracticable) but what will acquit and justify myself to those few persons and to those distant times which may take a concern in these affairs and in the Actors in them'." [" 'Falando por mim', escreveu ele, 'meu problema não é o que vai condenar o Sr. Hastings - algo que todos sabemos ser impraticável -, mas o que irá me absolver e justificar diante daquelas poucas pessoas e daqueles tempos distantes que talvez venham a se interessar por esse caso e pelos Atores nele envolvidos'.’] (Pág. 1081.)

${ }^{57}$ Whelan, 1996: "In 1786, Burke launched the prosecution by presenting twenty-two 'Articles of Charge' against Hastings to the House of Commons, of which only one was actually defeated. In the end, however, because of a lack of parliamentary time, Hastings was impeached on twenty-one charges, which covered only eight of the original ones. Burke drew up these formal 'Articles of Impeachment', which were forwarded to the House of Lords in 1787. In view of the numerous delays attending the proceedings, however, Burke and the other managers decided to restrict themselves to what they regarded as
} 
Outros quatro anos de defesas e respostas se seguiram até que, em 1795, foi dado o veredito final: absolvição de Hastings.

Dos cerca de duzentos e cinquenta lordes envolvidos no caso Hastings, apenas vinte e nove julgaram-se suficientemente familiarizados com a questão para votar. Dentre esses, não mais do que seis condenaram sem reservas o ex-governador de Bengala. A Companhia das Índias Orientais reembolsou todas as despesas jurídicas de Warren Hastings, concedendo-lhe, em seguida, um estipêndio anual de quatro mil libras e um empréstimo - sem juros - de cinquenta mil libras. Em 1804, foi ele dispensado do pagamento desse empréstimo. Quatro anos depois, um dos navios da "John Company" foi batizado com o nome de Warren Hastings. Em 1813, a Universidade de Oxford outorgou-lhe o título honorário de doutor em leis. No mesmo ano, os membros de um comitê parlamentar agradeceram seus conselhos sobre a Índia saudando-o como se costumava saudar a nobreza. Em 1818, aos oitenta e cinco anos, vinte deles transcorridos em um confortável retiro na casa de seus sonhos, Warren Hastings faleceu nas terras de sua família em Daylesford ${ }^{58}$.

A defesa de Hastings procurou a todo o momento valer-se das limitações do poder de alcance da lei. Saiu-se, em suma, vitoriosa, apostando na dificuldade de se provar de maneira válida nos tribunais a prática de crimes de corrupção cuja evidência material pode muitas vezes ser ocultada ou destruída ${ }^{59}$. O contexto de toda essa história, todavia, sugere que a absolvição de Hastings não tenha resultado propriamente da falta de provas contra ele, mas sim da corrupção generalizada dos mandatários britânicos. Provas havia, diretas e indiretas, das iniquidades do ex-governador-geral de Bengala, mas a

the four strongest charges, and on this basis they finally concluded their case in May 1791. The trial then continued, through Hastings defense and Burke's 'Reply', until the final verdict was handed down in 1795.

Of the four charges on which Hastings was finally tried, two ('Presents' and 'Contracts') were accusations of 'pecuniary corruption'. The others (the 'Benares' and the 'Begams of Oudh' charges) focused on instances of 'open violence and injustice' (...) or oppression (...)." [“Em 1786, Burke deu início à acusação apresentando vinte e dois 'Artigos Acusatórios' contra Hastings na Câmara dos Comuns, dos quais apenas um de fato foi derrubado. No final, contudo, em razão da falta de tempo parlamentar, Hastings enfrentou o processo de impeachment com base em vinte e uma acusações que cobriam apenas oito das acusações originais. Burke, enfim, ordenou esses 'Artigos de Impeachment' e os enviou à Câmara dos Lordes em 1787. Todavia, diante dos vários atrasos de procedimentos, Burke e seus companheiros decidiram restringir-se ao que entendiam ser as quatro maiores acusações, e sob essa base eles finalmente concluíram o caso em maio de 1791. O julgamento, então, continuou - entre a defesa de Hastings e as 'Respostas' de Burke - até o veredito final dado em 1795.

Das quatro acusações que compuseram o julgamento final de Hastings, duas - 'Presentes' e 'Contratos' - estavam ligadas à 'corrupção pecuniária'. As outras - 'Benares' e 'Begams de Oudh' - estavam focadas em episódios de 'violência crua e injustiça’ (...) ou opressão (...).”] (Págs. 64 e 65.)

58 Noonan, Jr., 1982, págs. 1074 e 1075.

${ }^{59}$ Burke, 1877: "My lords, you see two things (...) for you to consider in the judgement of this great cause, which is the cause of nations. The first thing for you to consider is the declaration of the culprit at your bar, that a person may be pursued by the cries of a whole people; that documents the most authentic and satisfactory, but deficient in technical form, may be produced against him; in short, that he may be guilty of the most enormous crimes, and yet that legal proofs may be wanting. This shows you how seriously you ought to consider, before you reject any proof upon the idea that it is not technical legal proof." ["Meus senhores, diante de vós há duas coisas (...) a ser consideradas no julgamento desta grande causa, que é a causa das nações. A primeira coisa a ser considerada é a declaração do acusado segundo a qual, ainda que uma pessoa seja perseguida pelo clamor de todo um povo, que contra ela sejam brandidos os documentos mais autêncticos e satisfatórios - mas deficientes na forma técnica - e que de fato ela seja culpada dos crimes mais monstruosos, mesmo assim é possível que não haja provas legais para condená-la. Isso mostra quão séria tem de ser a vossa avaliação antes de rejeitar qualquer prova sob a alegação de que não se trata de uma prova tecnicamente legal.”] (Pág. 365.) 
rede imoral de interesses que unia a elite britânica - Coroa, parlamento e até mesmo o clero ${ }^{60}$ - à sua ramificação indiana é que parece de fato ter impedido a condenação de um homem cuja riqueza se havia construído mediante a troca constante de favores com algumas das figuras mais poderosas da Inglaterra. Não resta dúvida que Burke enxergava a situação dessa forma, e sua estratégia de acusação foi montada, não tanto para condenar Hastings, o que lhe parecia bastante improvável, mas para alijá-lo da vida pública e para restaurar a moralidade política com uma reforma no governo britânico.

Sob essa ótica, Burke foi relativamente bem-sucedido. Atrelando aos crimes de corrupção uma série de outros delitos mais graves e unindo-os todos na ideia de injustiça como transgressão da lei moral incutida por Deus na alma humana, o irlandês, confiando no senso moral comum dos homens, mostrou de maneira convincente a relação direta entre corrupção e destruição econômica, política e social, tornando patente a necessidade de uma reorientação dos rumos pelos quais se enveredara a administração da coisa pública na Índia e na Inglaterra. Ainda que a retórica empregada contra Hastings, na opinião de alguns especialistas modernos ${ }^{61}$, possa ter sido pesada a ponto de comprometer a credibilidade da acusação, o fato é que, mesmo não tendo vencido nos tribunais, Burke obteve a humilhação pública de um homem poderoso, exemplo que sem dúvida imprimiu certo temor no espírito orgulhoso de políticos tão imorais quanto o ex-governador-geral de Bengala.

Não se humilha, contudo, um homem diante da justiça, a não ser que ele a tenha primeiro humilhado com a injustiça ${ }^{62}$. A acusação de injustiça foi, portanto, o centro do argumento acusatório de Burke, centro esse em torno do qual orbitaram os quatro grandes tópicos - propinas, contratos, Benares e begams de Oudh - que resumiam os crimes cometidos por Hastings na Índia. "Eu afirmei (...) que esta acusação recriminatória consistia de duas partes distintas, injustiça e retardo. À injustiça devemos responder pela[s] (...) provas da acusação que trouxemos diante dos senhores $(\ldots)^{63}$ ”. Tratar desses

\footnotetext{
${ }^{60}$ Especificamente quanto ao clero, Noonan Jr., 1982, comenta que havia bispos entre os lordes da Inglaterra e que alguns deles mantinham com a "Companhia" relações indecorosas. Ele cita um comentário irônico de Burke a respeito dessa situação: "The humility of the Bishops will leave the honour of vindicating the Christian religion to others". ("A humildade dos bispos deixará para outros a honra de justificar a religião cristã.”) (Pág. 1103.)

${ }^{61}$ Noonan, Jr., 1982. "If Hastings could have been tried like a common criminal at Old Bailey for the single offense of taking a bribe, Burke might have secured his conviction. But he catered to the popular temptation to think a bad man must be thoroughly bad: 'There is, my Lords, always a close connection between vices of every description'. Facing a political tribunal and making his own judgement of how seriously bribery would be rated by it, Burke took the Ciceronian route." ("Se Hastings pudesse ter sido julgado como um criminoso comum em Old Bailey pela simples ofensa de ter aceitado suborno, Burke talvez tivesse conseguido assegurar sua condenação. Ele, porém, deixou-se levar pela tentação popular de pensar que um homem mau é invariavelmente mau em todos os aspectos: 'Há, meus senhores, sempre uma estreita conexão entre vícios de todos os tipos'. Enfrentando um tribunal político e formando seu próprio julgamento de como a acusação de suborno seria encarada por esse tribunal, ele enveredou pela rota ciceroniana.") (Pág. 1104.)

${ }^{62}$ Cícero, no De officiis (Loeb, 1928, pág. 89), diz que a tarefa de acusar um homem é muito delicada e por isso deve ser levada extremamente a sério. "All this the citizen who is patriotic, brave, and worthy of a leading place in the state will shun with abhorrence (...). Besides, he will not expose anyone to hatred or disrepute by groundless charges, but he will surely cleave to justice and honour (...)." [“Tudo isso o cidadão patriótico, corajoso e merecedor de um lugar digno no Estado irá evitar com horror (...). Ademais, não irá ele expor ninguém ao ódio ou ao descrédito com base em acusações infundadas, mas irá seguramente se agarrar à justiça e à honra.”]

${ }^{63}$ Burke, 1877. "I next stated (...) this recriminatory charge consisted of two distinct parts: injustice and delay. To the injustice we are to answer by the (...) proof of the charges which we have brought before you (...).” (Pág. 1.)
} 
tópicos é, pois, tratar de diferentes aspectos de uma injustiça que, contrariando a lei de Deus, solapa as bases da civilização e condena os homens a um destino sombrio.

O termo propina parece ser mais adequado para traduzir o que Warren Hastings e seus defensores chamavam de "presents". Burke explicou em seus discursos acusatórios que os "presentes" recebidos pelo ex-governador-geral de Bengala eram na verdade uma forma de extorsão. Clive e outros pioneiros ingleses haviam enriquecido à custa dos "presentes" obtidos dos governantes-fantoches que lhes eram subordinados, estabelecendo com isso um precedente seguido à risca por seus sucessores. Justificandose, diziam eles que era esse um costume antigo visto por governantes e governados como normal e necessário para a estabilidade política dos territórios indianos. Como já se observou, Burke não aceitava a ideia de que algo tido como crime pelos britânicos não fosse igualmente criminoso para os indianos. E esses "presentes" eram de fato vistos como propinas criminosas pelos ingleses, tanto que haviam sido condenados formalmente pela lei britânica.

[...] Em primeiro lugar, tendes a prova de que ele aceita propinas e de que pratica transações corruptas (...); porém, diz ele que tudo isso foi feito em vista do bem público ${ }^{64}$. (...)

[...] [É muito difícil acreditar] que qualquer nativo da Índia tenha voluntária e gratuitamente dado seu dinheiro ao mencionado Warren Hastings, isto é, sem perspectiva nenhuma de algum benefício em retorno ou sem o temor de represálias em caso de recusa ${ }^{65} .(. .$.$) .$

[...] Nós sabemos que uma nuvem de gafanhotos individualmente desprezíveis pode ser mais devastadora para um país do que Genghis Khan ou Tamerlão ${ }^{66}$.

O exemplo de Genghis Khan, de Tamerlão e de outros conquistadores orientais muitas vezes era usado pelos defensores de Hastings como justificativa de certas ações injustas tidas como necessárias à governabilidade dos territórios indianos. A lembrança desses homens não servia propriamente para defender a corrupção e as propinas em si mesmas, mas sim para explicar que um governante, na Ásia, para ser eficaz tinha muitas vezes de cometer atos que, na Inglaterra, por exemplo, seriam considerados imorais e injustos. Burke teve de combater esse relativismo, e ao combatê-lo acabou por enfrentar a autoridade de um Montesquieu, segundo o qual o despotismo era a forma característica e inevitável dos governos asiáticos ${ }^{67}$. Para desmontar essa linha de raciocínio, Burke mergulhou a fundo na história da Índia, notadamente nos escritos jurídicos hindus e muçulmanos que regulavam a vida civil da imensa maioria dos habitantes do Império Mogol, o que lhe permitiu concluir que os grandes conquistadores asiáticos, Tamerlão e Genghis Khan entre eles, conquanto tivessem obtido seus domínios de forma

\footnotetext{
${ }^{64}$ Burke, 1877: "For, in the first place, you have proof that he does take bribes, and that he has corrupt dealings (...); but he says that he has done it from public-spirited motives". (Pág. 353.)

${ }^{65}$ Whelan, 1996, citando Burke: "It was simply not credible 'that any native of India had voluntarily and gratuitously given money privately to the said Warren Hastings, that is, without some prospect of a benefit in return, or some dread of his resentment, if he refused'." (Págs. 72 e 73.)

${ }^{66}$ Whelan, 1996, citando Burke: "We know that a swarm of locusts, although individually despicable, can render a country more desolate than Genghis Khan or Tamerlane.” (Pág. 74.)

${ }^{67}$ Whelan, 1996. "Montesquieu concluded that despotic government was standard for all major Asian nations, an influential thesis that Burke sought to refute." ("Montesquieu concluiu que o governo despótico era o padrão de todas as grandes nações asiáticas, uma influente tese que Burke buscou refutar.”) (Pág. 5.)
} 
obscura, misteriosa e questionável, para mantê-los tiveram de observar uma série de costumes condizentes com a lei natural comum a toda a humanidade - compilados na forma de leis civilizatórias. Ironicamente, Burke utilizou contra Hastings a autoridade de um dos homens que ajudaram a montar a defesa do ex-governador-geral de Bengala, o erudito Nathaniel Halhed. Halhed escrevera, a pedido do próprio Hastings, um Código das Leis Hindus ${ }^{68}$, com o propósito de facilitar a tarefa da supremacia governamental britânica na Índia. Esse trabalho, no entanto, desmentia quem procurasse justificar a própria injustiça com base numa suposta tradição despótica do Oriente. Pelo contrário, assim como no Ocidente, as leis e os costumes que haviam viabilizado as civilizações orientais enraizavam-se naquele sentimento humano comum de justiça que para Burke integrava a moralidade inscrita por Deus no coração dos homens.

[...] Esta é a maneira como ele trata um ato do parlamento! No lugar dos atos parlamentares ele coloca sua própria vontade arbitrária. Essa, diz ele, é a única lei do país que ele governa, tal como se vê no que ele chama de institutos arbitrários de Genghis Khan e Tamerlão. É nessa vontade arbitrária que ele se afirma, deixando de lado a lei hindu, a lei maometana e a lei do seu próprio país ${ }^{69}$.

Essa arbitrariedade que Hastings entendia ser a "lei" oriental refletiu-se também na maneira de lidar com os contratos relativos aos grandes negócios da "United Company". Usando como parâmetro, não a competência e a habilidade comercial, mas a real ou a potencial capacidade de influência política das pessoas, Hastings fazia das prerrogativas comerciais britânicas na Índia uma fonte de riqueza e poder para si mesmo e para seus aliados e patronos. Foi o que aconteceu em 1780, quando Stephen Sulivan, filho de Laurence Sulivan, um dos mais eminentes diretores da "Companhia", foi enviado a Bengala. Hastings emprestou-lhe dez mil libras e concedeu-lhe - por quatro anos - a exploração de um dos mais lucrativos negócios da "E.I.Co.”: o comércio de ópio ${ }^{70}$. Em contrapartida, Laurence Sulivan agia como um dos grandes defensores de Hastings na Leadenhall Street ${ }^{71}$, em Londres, onde se localizava o quartelgeneral da Companhia das Índias Orientais. $\mathrm{Na}$ visão de Burke, essa promiscuidade dos contratos entre o público e o privado, irmã siamesa que era do sistema de propinas que permeava todo o governo britânico na Índia, provocando desordem no andamento natural das transações comerciais entre as pessoas, resultava na ruína econômica da sociedade.

[...] [A] mesma soma pode tornar-se privada ou pública, ao gosto do receptador.

\footnotetext{
${ }^{68} \mathrm{O}$ título original do livro de Halhed é $A$ Code of Gentoo Laws, or, Ordinations of the Pundits, from a Persian Translation, made from the Original, written in the Shanscrit Language.

${ }^{69}$ Burke, 1877: “(...) This is the manner in which he treats an act of parliament! In the place of acts of parliament he substitutes his own arbitrary will. This he contends is the sole law of the country he governed, as laid down in what he calls the arbitrary institutes of [Genghis] Khan and Tamerlane. This arbitrary will he claims, to the exclusion of the Gentoo law, the Mahomedan law, and the law of his own country." (Págs. 3 e 4.)

70 Whelan, 1996, pág. 85.

${ }^{71}$ Noonan, Jr., 1982, pág 1077.
} 
[...] Um sistema de propinas privadas como fonte de receita (...) deve necessariamente arruinar o país em que ele prevalece e desgraçar a nação que o emprega, destruindo-lhe, ao final, todas as riquezas.

[...] É evidente que [num sistema como esse] os poderes governamentais, em algum momento, serão vistos pelos nativos como se estivessem à venda num leilão. A própria natureza dessas transações tende a ensinar os nativos a corromper com dinheiro os servidores da Companhia, tornando-os, assim, menos desejosos - ou menos aptos, ou ambas as coisas - de cumprir seus contratos com o Estado ${ }^{72}$.

Esse sistema injusto marcado pela arbitrariedade do governante, pela confusão entre o público e o privado e pelo sistema de troca de favores e extorsão como modus operandi administrativo mostrou toda a sua capacidade destrutiva no caso de Benares. Considerada sagrada, a cidade de Benares era o centro de um distrito ao mesmo tempo rico e estrategicamente importante para os britânicos. Entre 1738 e 1780, a Companhia das Índias Orientais manteve boas relações com o rajá de Benares, Balwant Singh, de fato um governante independente, embora oficialmente subordinado ao nababo de Oudh. Quando Chait Singh, filho de Balwant, assumiu o poder no lugar do pai, a "E.I. Co." reconheceu a legitimidade da sucessão. Em 1775, o nababo Asaf al-Daula cedeu as prerrogativas de Oudh sobre Benares à "John Company" por meio do Tratado de Faizabad. Hastings e seus conselheiros estavam interessados em garantir o controle de Benares para que a cidade servisse como uma "zona-tampão" destinada a melhorar as condições de defesa de Bengala. Chait Singh reconheceu a soberania britânica sobre seus territórios e, em 1776, entrou em um acordo com a "Companhia" por meio do qual ficaram estabelecidas suas obrigações tributárias e militares com os ingleses.

Dois anos depois, a guerra contra os Marathas em pleno curso e renovadas as animosidades contra a França, Hastings começou a mobilizar seu aparato diplomático e militar em defesa dos domínios britânicos na Índia. Exigiu-se, então, de Chait Singh, o pagamento de subsídios de guerra em valor superior ao estipulado no acordo de 1776. O rajá, contrariado, pagou o que lhe estava sendo exigido, ainda que tardiamente. Em 1780, obrigado que era de manter preparadas tropas para emprego imediato, não atendeu de pronto a demanda britânica por auxílio militar. No verão do ano seguinte, o então governador-geral de Bengala, furioso e amparado por uma quantidade de soldados proporcional e arriscadamente menor do que sua fúria, dirigiu-se a Benares disposto a impor ao rajá uma multa exorbitante pela hesitação. Como Chait Singh não lhe pareceu suficientemente submisso, Hastings ordenou fosse ele confinado em seu próprio palácio. Isso provocou uma grande rebelião em Benares e nas regiões adjacentes, que não foi contida senão mediante o derramamento do sangue de muita gente,

\footnotetext{
72 Whelan, 1996, citando Burke: “(...) the same Sum may become private Property or public, at the Pleasure of the Receiver. (...) A system of private bribery for a revenue (...) must ruin the Country where it prevails, must disgrace the Country that uses it, and finally end in the destruction of the revenue.

(...) It is plain that the Powers of Government must, in some Way or other, be understood by the Natives to be at Sale ... The very Nature of such Transactions has a Tendency to teach the Natives to pay a corrupt Court to the Servants of the Company; and they must thereby be rendered less willing, or less able, or perhaps both, to fulfill their Engagements to the State." (Págs. 82 e 83.)
} 
inclusive de militares britânicos e de sepaios ${ }^{73}$. Em meio à confusão, Chait Singh escapou, e em seu lugar foi colocado um novo rajá, que passou a ser controlado pelos britânicos com rédea curta.

Hastings justificou todas essas ações com base na ideia de razão de estado ${ }^{74}$, em nome da sobrevivência do império britânico na Índia. Já para Burke as razões de Hastings eram a cobiça e a ganância, momentaneamente vantajosas a uma cabala de ladrões, mas no fim danosas a eles mesmos e ao estado. As injustiças do então governador-geral de Bengala formavam um conjunto interligado de quebra de contrato - não por motivo de força maior, mas por ambição e arrogância -, extorsão, não observância do devido processo legal, destruição econômica da sociedade, desde os seus estratos superiores até os mais simples dos indivíduos, e, finalmente, rebelião.

\begin{abstract}
Fazer demandas públicas injustas; aceitar favores pecuniários privados em razão dessas demandas e, sob o pretexto da postergação e da recusa, perseguir sem misericórdia um benfeitor; negar-se a ouvir suas justificativas; prendê-lo em sua capital e em seu palácio, diante de todo o povo - dando, assim, ocasião a uma insurreição e, utilizando essa insurreição como argumento, recusar todo e qualquer tratado ou explicação; retirá-lo [o benfeitor] de seu governo e de seu país; excluí-lo de uma anistia geral, enviando-o assim por toda a Índia como um fugitivo a testemunhar a vergonha do governo britânico diante de todas as nações (...). [E]sses são os procedimentos cujos paralelos, para a honra da natureza humana, espera-se sejam poucos na História ${ }^{75}$.
\end{abstract}

Quando Burke diz que, para a honra da natureza humana, é de se esperar que as ações de Hastings não encontrem muitos paralelos na história, ele está assumindo, em conformidade com a ideia de uma lei de Deus comum a todos os homens, que o relacionamento entre as nações - isto é, entre as pessoas de diferentes nações - não pode ter como parâmetro senão a razão e a moralidade comuns a todos os seres humanos. Essa visão, compartilhada por pensadores antigos como Cícero, também permeava os pontos de vista de um autor contemporâneo de Burke: o jurista suíço Emmerich de Vattel ${ }^{76}$.

\begin{abstract}
Tendo agora, como sempre, afirmado que a lei das nações é a lei da Índia e a lei da Europa, pois é a lei da razão e a lei da natureza, extraída das fontes puras da moralidade, do bem público e da equidade natural, bem como reconhecida e ordenada pelo trabalho de homens instruídos, remeto os senhores a Vattel, livro 1, capítulo 16, em que ele trata da violação de tais acordos: o protetor recusando-se a dar proteção ou o protegido recusando-se a cumprir o que foi combinado. Meu desígnio, ao remeter os senhores a esse autor, é provar que Cheit [Singh], longe de ser culpável pelo levantamento de objeções à demanda não autorizada feita a ele pelo Sr. Hastings, tinha na verdade a obrigação de agir como agiu, pois se outra coisa tivesse feito teria colocado em risco todo o acordo em que se fundamentavam sua sujeição e sua proteção. (...).
\end{abstract}

\footnotetext{
73 Sepaios eram soldados indianos a serviço dos britânicos.

${ }^{74} \mathrm{~A}$ noção moderna de razão de estado (raison d'état) está ligada às concepções maquiavélicas segundo as quais a moralidade está subordinada ao interesse político do Estado.

${ }^{75}$ Whelan, 1996, citando Burke: "To urge unjust public Demands; to accept private pecuniary Favours in the Course of those Demands; and, on the Pretence of Delay or Refusal, without Mercy to persecute a Benefactor; to refuse to hear his Remonstrances; to arrest him in his Capital, in his Palace, in the Face of all the People; - thus to give Occasion to an Insurrection, and, on Pretext of that Insurrection, to refuse all Treaty or Explanation; to drive him from his Government and his Country; to proscribe him in a general Amnesty; and to send him all over India, a Fugitive to publish the Shame of British Government in all the Nations (...). (...) these are Proceedings to which, for the Honour of human Nature, it is hoped few Parallels are to be found in History.” (Pág. 172.)

76 O jurista suíço Emmerich de Vattel, nascido em 1714 e morto em 1767, ganhou notoriedade com o livro Les Droits des gens (1758), no qual aplicou o direito natural às relações internacionais.
} 
Nós defendemos Cheit [Singh] em apoio aos princípios da equidade natural e da lei das nações - que é o direito natural de todos nós ${ }^{77}$.

Outra transgressão explícita do direito natural comum a todos os homens deu-se no caso das begams de Oudh. Begam era um título de nobreza das mulheres muçulmanas do Império Mogol, e as begams de Oudh, especificamente, eram a mãe enviuvada e a avó de Asaf al-Daula, herdeiro do trono de Oudh. Oudh era uma vasta província mogol situada a nordeste de Bengala. Clive - inicialmente - e depois Hastings haviam estabelecido uma aliança estável com o severo e competente Shuja al-Daula, nababo de Oudh, ajudando-o a defender e a ampliar seus territórios. O objetivo estratégico dos britânicos com essa aliança era o de sempre: fazer de Oudh uma "zona- tampão" destinada a proteger as possessões da "John Company”. As tropas britânicas estacionadas em Oudh eram mantidas pelos recursos da província.

Em 1775, Shuja al-Daula morreu, e seu filho, Asaf al-Daula, assumiu o trono de Oudh. O falecido nababo havia contraído muitas dívidas com os ingleses, porém, graças à sua capacidade administrativa, manteve-as sob controle durante sua vida. O filho, mais fraco e não tão competente, herdou os problemas do pai, mas não a habilidade para resolvê-los. Hastings, então, quis aproveitar-se da tibieza do novo nababo para retirar de Oudh tudo o que fosse possível. Forçando o fraco Asaf a esfolar seu próprio povo, Hastings conseguiu destruir a reputação do governante, e essa reputação destruída condenou o nababo a depender dos britânicos para conseguir comandar seus próprios domínios.

O curso invariável da política da Companhia é este: ou ela entrona algum príncipe tão odioso a
ponto de não poder sustentar-se senão mediante o apoio dela ou ela o torna odioso para a
população utilizando-o como instrumento de governo. Nesse caso, a autoridade do governante
é mantida por meio de tropas suficientemente numerosas. Para que não lhe falte auxílio, um
cavalheiro civil, chamado de residente, é mantido em sua corte e, sob o pretexto de cuidar do
pagamento devido às tropas, passa ele mesmo a controlar todas as receitas. Sob uma tão
previdente gerência, os débitos logo se acumulam ... até que, passo a passo, todo o dinheiro que
entra - e com isso todo o poder do país - é entregue nas mãos do residente. E não falta aos
militares virtude para tentar igualar os ganhos do departamento civil. Porções do país são, pois,
entregues aos homens de farda. Parece-lhes, então, apropriado converter os oficiais em
arrecadadores de impostos. Assim, situada entre o bem remunerado estamento civil e o bem
recompensado estamento militar, é fácil imaginar a sorte dos nativos ${ }^{78}$.

77 Burke, 1877. "Now having contended, as we still contend, that the law of nations is the law of India as well as of Europe, because it is the law of reason and the law of nature, drawn from the pure sources of morality, of public good, and of natural equity, and recognized and digested into order by the labour of learned men, I will refer your lordships to Vattel, book 1, cap. 16, where he treats of the breach of such agreements, by the protector refusing to give protection, or the protected refusing to perform his part of the agreement. My design, in referring you to this author, is to prove that Cheit Sing, so far from being blamable in raising objections to the unauthorized demand made upon him by Mr. Hastings, was absolutely bound to do so, nor could he have done otherwise, without hazarding the whole benefit of the agreement upon which his subjection and protection were founded.

We contend in favour of Cheit Sing, in support of the principles of natural equity and of the law of nations, which is the birthright of us all." (Págs. 10 e 11.)

${ }^{78}$ Whelan, 1996, citando Burke: “The invariable course of the Company's policy is this: Either they set up some prince too odious to maintain himself without the necessity of their assistance; or they soon render him odious, by making him the instrument of their government. In that case troops are bountifully sent to him to maintain his authority. That he should have no want of assistance, a civil gentleman, called a Resident, is kept at his court, who, under pretence of providing duly for the pay of these troops, gets assignements on the revenue into his hands. Under his provident management, debts soon accumulate... until, step by step, the whole revenue, and with it the whole power of the country, is delivered into his hands. The military do not behold without a virtuous emulation the moderate gains of the civil department... Tracts of country are delivered over to their discretion. Then it is found proper to convert their commanding officers into farmers of revenue. Thus, 
Oudh não era pobre. Suas riquezas, no entanto, estavam nas mãos dos civis e militares que, com a anuência de Hastings, controlavam o tesouro. Assim, obviamente, Asaf al-Daula não tinha condições de quitar a dívida de seu pai com a "United Company", e isso o governador-geral de Bengala não podia perdoar. As riquezas da mãe e da avó do tíbio nababo pareceram então bastante atraentes a Warren Hastings. Passando por cima da lei de Deus, o então governador-geral de Bengala forçou Asaf a sufocando no peito o sentimento natural de amor em relação à mãe e à avó - extorquir a riqueza e o sustento das begams para entregá-los à "Companhia”. O caudilho britânico, evidentemente, dizia que com isso prestava um grande serviço à Inglaterra, aumentando-lhe o exchequer ${ }^{79}$.

\begin{abstract}
Agora, meus senhores, podeis ver que todas essas propriedades (...) ou eram jaghires destinados aos familiares mais próximos do nababo, concedidos por seu pai à sua mãe e, antes disso, pelo pai de seu pai à sua avó e a Salar Jung, seu tio, ou eram a propriedade dos nobres mais eminentes. (...). O Sr. Hastings, na intenção de incluir no confisco pessoas sem valor, acabou por confiscar os jaghires de homens inocentes e virtuosos de elevada estatura e também os dos parentes de sangue do nababo, reduzindo-os todos a um estado de dependência e degradação. (...) Este é o relato que ele lhes dá de sua honra, de sua justiça e de sua política nesses procedimentos ${ }^{80}$.
\end{abstract}

Resumidos nesses quatro tópicos apresentados, quais sejam, propinas, contratos, Benares e begams de Oudh, Burke procurou tornar patente nos tribunais ingleses a imoralidade e a injustiça do governo de Warren Hastings na Índia. A bem da verdade, para o parlamentar britânico a administração de Hastings não podia propriamente ser chamada de governo, visto que se aproximava muito mais da ação conjunta de uma gangue de criminosos coordenada por um caudilho implacável. Com efeito, para o irlandês a ideia de governo e de estado sempre esteve ligada à do respeito à moralidade e ao senso de justiça incutidos por Deus na alma humana, de sorte que os desmandos de Hastings na Índia eram vistos antes como crimes, não apenas contra a Inglaterra e a Índia, mas contra a humanidade como um todo. A falta de moralidade do governo da "Companhia" na Índia ensejou uma verdadeira empreitada de ladrões.

\title{
DA MORALIDADE NO GOVERNO
}

Para Burke, assim como para Cícero, há uma moralidade - comum a todos os homens - que está acima de qualquer discussão e se apresenta como um dado evidente da realidade. Essa moralidade foi incutida por Deus no coração de todos os seres humanos, de sorte que em qualquer lugar do mundo, na

\footnotetext{
between the well paid civil, and well rewarded military establishment, the situation of the natives may be easily conjectured." (Pág. 180.)

${ }^{79} \mathrm{O}$ exchequer é o tesouro nacional britânico.

${ }^{80}$ Burke, 1877: "Now, my lords, you see that all these estates (...) were either jaghires for the Nabob's own immediate family, settled by his father upon his mother, and by his father's father upon his grandmother, and upon Salar Jung, his uncle, or were the property of the most considerable nobility (...). Mr. Hastings, to effect the inclusion of the worthless in the confiscation, confiscates the jaghires of the innocent and the virtuous men of high rank, and of those who had all the ties of nature to plead for the Nabob's forbearance, and reduced them to a state of dependency and degradation. (...)

This is the account he gives you himself of his honour, his justice, and his policy in these proceedings." (Págs. $166 \mathrm{e}$ 167.) (Jaghire era uma espécie de direito pessoal ou grupal às receitas oriundas de um distrito indiano.)
} 
Índia como na Inglaterra, um ato pode ser claramente percebido como moral, na medida em que obedece a essa lei inscrita na alma humana, ou imoral, quando a desobedece. Foi com base nessa concepção que Burke enfrentou nos tribunais os defensores de Hastings, para os quais a moralidade, assim como a cultura em geral, variava de um povo para outro. Para eles, o que se chamava de crime na Inglaterra nem sempre correspondia a um delito na Índia, e era assim, por exemplo, que chamavam de "presentes" entre os indianos aquilo que se identificava como propina e extorsão entre os ingleses. Burke considerava essa linha de argumentação uma farsa, montada exclusivamente com o intuito de defender com perfídia e cinismo um esquema milionário de corrupção que favorecia uma vasta rede de civis, militares, nobres, políticos e outros representantes da elite inglesa, incluindo sua ramificação indiana. Na concepção de Burke, um "negro" - como os ingleses chamavam os indianos naquela época - percebia perfeitamente a imoralidade da elite inglesa na Índia e sofria com isso. Além disso, os atos imorais dessa elite, longe de promover a prosperidade do governo, como diziam os defensores de Hastings, não eram convenientes ao estado, pois na realidade causavam a sua ruína a longo prazo. De fato, Burke tentou a todo o momento mostrar que, devido aos procedimentos excusos da "John Company", milhares de indianos ficaram sujeitos à miséria e ao desespero, já que as riquezas das colônias britânicas na Índia eram drenadas por um esquema de corrupção percebido como imoral em qualquer época e em qualquer lugar. Ademais, procurou deixar claro como a conivência com um esquema desses era nociva à própria Coroa britânica. Para o parlamentar irlandês, era absurdo pensar que o senso de justiça dos indianos - senso esse que integrava a moralidade em sentido amplo - não percebia como injustos e imorais os abusos de Warren Hastings e de seus comparsas de crime. Era evidente, para ele, que o que ocorria na Índia era injusto e imoral, em sentido absoluto, algo condenável aos olhos de qualquer homem com o senso moral preservado da corrupção, e por isso mesmo inconveniente, pois nocivo à comunidade humana e ao estado.

Como Santo Agostinho, Burke entendia que a justiça estava na base dos governos, os quais, sem ela, não passavam de empreendimentos criminosos. E empreendimento criminoso era o domínio da Companhia das Índias Orientais sobre as colônias britânicas na Índia sob as ordens de Warren Hastings. A defesa de Hastings muitas vezes alegava que, por razões de estado, certas atitudes questionáveis se faziam necessárias. Para Burke, contudo, isso era absurdo, pois, embora fosse ele um defensor da ideia de conveniência política, essa conveniência jamais poderia conflitar com o senso inato de moralidade e justiça de todos os seres humanos, senso esse que norteava a política e sobre o qual, em última instância, se fundava o próprio estado. Extorquir pessoas sob o pretexto de que essa seria uma ação aceita dentro de um determinado contexto e até mesmo necessária ao bom andamento da coisa pública, argumento utilizado, não evidentemente com essas palavras, pela defesa de Hastings, era, para Burke, uma afirmação infundada, já que os princípios da boa política, indissociavelmente atrelados à condução do estado, eram os da moralidade ampliada. Em suma, um governo sem justiça, ou, em outras palavras, sem moralidade, não era exatamente um governo, mas um emprerendimento criminoso. Um empreendimento desse tipo 
era o que ocorria na Índia e que se tentava defender, contra os esforços de Burke, sob a ideia de razão de estado.

Como criminosos, Warren Hastings e seus comparsas sacrificavam - assim pensava Burke - toda e qualquer moralidade por dinheiro. O que eles buscavam, cruamente falando, era dinheiro a qualquer custo. Para isso passavam por cima das leis da moralidade incutidas por Deus no coração humano, incluindo até mesmo os laços mais básicos da unidade familiar, como fez Hastings no caso das begans de Oudh, colocando um filho contra os direitos legítimos de sua mãe em razão da busca inescrupulosa de riqueza. A elite inglesa, no entanto, parecia fazer vistas grossas a esses desmandos e a esses abusos, visto que lucrava bastante - em detrimento do povo indiano como um todo - com os negócios da "Companhia". Parecia que serviam, a elite inglesa e sua ramificação indiana, antes ao dinheiro do que a Deus, tanto que, mesmo diante de todas as evidências trazidas por Burke nos tribunais, Hastings foi absolvido dos crimes cometidos na Índia. Mas Burke sabia disso. Sabia inclusive que a condenação de Hastings era algo improvável. Ainda assim, levou adiante, ao longo de vinte e dois anos, um processo complexo e perigoso. Tinha a vista fixada na posteridade, em sua reputação como homem público, e também num futuro mais imediato, de reforma moral do governo inglês. Nesses pontos, obteve sucesso. Com o processo que moveu contra Hastings conseguiu, ainda em sua época, pelo menos alijá-lo da vida pública, assustando outros políticos imorais e abrindo caminho para uma reforma moral geral no governo britânico. Por fim, quanto à imagem diante da posteridade, a defesa que fez ele da moralidade e da justiça nos tribunais do século XVIII serve ainda hoje de inspiração a todos aqueles que lutam contra a corrupção e a imoralidade na política e nos governos no mundo todo.

\section{BIBLIOGRAFIA}

AGOSTINHO, Aurélio. A Cidade de Deus. Tradução, prefácio, nota biográfica e transcrições de J. Dias Pereira. 2.ed. Lisboa: Fundação Calouste Gulbekian, 1996.

ARMITAGE, David. "Edmund Burke and reason of state". Journal of the history of ideas, 2000.

BÍBLIA. Bíblia Sagrada. Edição pastoral. São Paulo: Paulus, 2002. Versão online. Disponível em:http://www.paulus.com.br/biblia-pastoral/_PYV.HTM. Acesso em 12 de dezembro de 2017.

BÍBLIA. Nova Bíblia Pastoral. São Paulo: Paulus, 2015.

BOEHNER, Philoteus; GILSON, Etienne. História da Filosofia Cristã. 13.ed. Petrópolis: Editora Vozes, 2012.

BURKE, Edmund. An Appeal from the New to the Old Whigs in consequence of some late discussions in Parliament, relative to the Reflections on the French Revolution. The Third Edition. London: J. Dodsley, Pall-Mall, 1791. The Works of the Right Honourable Edmund Burke. Vol. VIII. Speeches on the Impeachment of Warren Hastings, and Letters. London: George Bell and Sons, 1877. 
The Works of the Right Honourable Edmund Burke. Volume The Ninth. London: John C.

Nimmo, 1887.

The Works of the Right Honourable Edmund Burke. Vol. X. London: John C. Nimmo, 1887.

CANAVAN, Francis. Edmund Burke: Prescription and Providence. Durham: Carolina Academic Press, 1987.

CICERO, Marcus Tullius. De officiis: The Loeb Classical Library. With an English Translation by Walter Miller. London and New York, 1928.

49 FLORES, Jorge. Nas Margens do Hindustão: O Estado da Índia e a expansão mogol,ca. 1570-1640: Imprensa da Universidade de Coimbra. Julho, 2015.

GILSON, Etienne. Methodical Realism. Translated by Philip Trower with an Introduction by Stanley L. Jaki. USA: Christendom Press, 1990.

L'Esprit de la Philosophie Médiévale. Gifford Lectures (Université d'Aberdeen).

Deuxième Edition Revue. Paris : Librarie Philosophique J. Vrin, 1969.

KING JAMES BIBLE (online version): www.kingjamesbibleonline.org. (Acessada em 12 de setembro de 2017.)

LE GOFF, Jacques. As raízes medievais da Europa. Rio de Janeiro: Vozes, 2006.

NOONAN JR., John T. "The Bribery of Warren Hastings: The Setting of a Standard for Integrity in Administration”. In: Hofstra Law Review. Vol. 10, 1982.

STANLIS, Peter J. "Edmund Burke's Legal Erudition and Practical Politics: Ireland and the American Revoltution". In: First Principles (Web Journal), 2010. Acesso em 31 de agosto de 2017: www.firstprinciplesjournal.com.

WHELAN, Frederick G. Edmund Burke and India: political morality and empire. Pittsburgh: University of Pittsburgh Press, 1996. 